\title{
THE INFLUENCE OF TREES AND LANDSCAPING ON RENTAL RATES AT OFFICE BUILDINGS
}

\author{
by Robert J. Laverne ${ }^{1}$ and Kimberly Winson-Geideman ${ }^{2}$
}

\begin{abstract}
The environmental and economic benefits of trees have been studied relative to a variety of interests including their influence on real estate value. This study investigates the effect of trees and landscaping on office rental rates, based on a comparison of 85 office buildings that comprise 270 individual and unique leases in the Cleveland, Ohio, U.S., metropolitan area. Data that describe the quantity, functionality, and quality of landscaping were gathered from each of the buildings including landscape maturity, the percentage of ground cover (trees, turf, pavement, etc.), and functional attributes (building shade, noise buffer, space definition, recreation, visual screen, and aesthetics). Multiple regression analysis in the form of a hedonic equation was conducted to isolate the economic effects of landscaping. Office attribute data including lease information, physical attributes, and distance variables were used to calibrate the basic model, and landscaping data were added to the hedonic equation to determine if individual and/or interactive variables had any effect on contracted rental rates. The individual analysis of the variables showed a strong positive effect for those buildings with good landscaping aesthetics and building shade provided by trees. Conversely, landscaping that provides a good visual screen produced significant negative impacts on rental rates.
\end{abstract}

Key Words. Benefits of trees; real estate value.

\section{LITERATURE REVIEW}

A variety of benefits and costs associated with urban forests and landscape trees have been explored (Dwyer et al. 1992; Nowak 1993; McPherson et al. 1999), including energy conservation (McPherson and Rowntree 1993; Laverne and Lewis 1996; Simpson and McPherson 1996; Simpson 1998), ozone reduction (Nowak et al., in review), air quality (Scott et al. 1998; Beckett et al. 2000), carbon sequestration (Ip 1996; McPherson 1998; McPherson and Simpson 1999), stormwater management (Xiao et al. 1998), social involvement (Sommer et al. 1994; Sommer et al. 1995), and even the impact of trees on the reduction of domestic violence (Sullivan and Kuo 1996). Some of these benefits are quantifiable in terms of economics, while others can be measured only by social or environmental values.

Increasing attention has been devoted in the economic and real estate literature to the study and measurement of the impact of environmental externalities on property values (Des Rosiers et al. 2000; Taylor and Smith 2000). Much of this research has focused on the value added through trees and landscaping to residential properties. Peters (1971) was among the first to do so when he reported that shade trees contributed $19 \%$ (US\$57,000) to the total appraised value of a 2.8 ha parcel. Payne (1973) used traditional valuation techniques to conclude that the market value of a singlefamily home received a $7 \%$ premium due to arborescent vegetation, provided there were less than 30 trees on the lot. Morales (1980) used regression analysis to compare the sales price of homes with a substantial amount of tree cover to those with no tree cover. The values derived from the regression analysis showed that good tree cover added about $6 \%$ (US $\$ 2,686$ ) to the property value of the homes. Anderson and Cordell (1988) surveyed 844 single-family residential properties in Athens, Georgia, U.S., and found that landscaping with trees was associated with a $3.5 \%$ to $4.5 \%$ increase in sales price. Henry (1994) found that homes that received an excellent landscaping rating from a local landscaping professional could expect a sales price of about 4 to 5 percentage points higher (depending on the size of the lot) than equivalent houses with good landscaping. Homes that had a landscaping appeal far below (fair or poor) neighboring homes with excellent landscapes had a sales price $8 \%$ to $10 \%$ below equivalent homes with good landscaping appeal. Based on these and other studies, the Council of Tree and Landscape Appraisers (2000) suggests that "well-maintained landscapes can contribute up to 20\% to the value of an improved residential property."

Morales et al. (1976) combined factor analysis and multiple linear regression techniques to study 60 residential sales in Manchester, Connecticut. Four factors were developed that explained $83 \%$ of the variation in the data. These explanatory variables reflected location, house size, date of sale, and tree cover, respectively. The authors concluded that good tree cover could raise total sale price by as much as $6 \%$ to $9 \%$.

Additional work was conducted by Ulrich (1986), who hypothesized that the liking for urban scenes usually increased when trees and other vegetation were present. Referring to recent research in the field, he concluded that trees and other vegetation could be linked directly to health and, in turn, be related to economic benefits of visual quality. Compared to research focused on trees in residential areas, there is relatively little literature that reports on the effect of trees on commercial real estate. One study conducted by Wolf (1999) presented 32 photographic scenes of retail properties to two groups of participants (business professionals and consumers) who were asked to 
rank each scene according to their preference. The scenes that contained trees and landscaping received higher scores for preference from both groups than those scenes with little or few landscape plants. While both groups favored landscaping, the consumer group generally rated scenes with landscape plants higher than did the group of business professionals, suggesting that, in general, merchants have a lower appreciation for trees than do their customers. The results of this study find that consumers would be willing to pay, on average, a $12 \%$ premium for goods purchased in retail establishments that are accompanied by quality landscaping.

While property valuation literature is heavily focused on residential properties, there is a growing body of work that addresses the valuation of office space. Typically, the variables used in these analyses fall under one of three classifications: structural, lease, or distance. Clapp (1980) used a sample of 105 office buildings located in Los Angeles to regress the quoted annual rental rate per square foot of office space on building characteristics and three locational variables: distance to the central business district (CBD), average commute time of the building's workers, and square footage of office space within a 2-block radius. He found all three variables significant and with signs in the expected direction, although distance to the CBD had a substantially greater impact than the others. He inferred from this study that firms are willing to pay a premium for access to face-toface contact, especially those within the CBD.

Several other studies have attempted to address variation in office rents. Wheaton (1984) studied the impact of inter-jurisdictional tax rates on rent in Boston. This study included building characteristics as well as the number of transit lines within a mile of the building, number of highways leading in and out of the town in which the building was located, the percentage of households in the town with a college education, and the ratio of the office's floor area to the building's floor area. He found that inter-jurisdictional property tax differentials were not borne by office tenants, but rather access to employees was a much more powerful determinant in rent variation.

Vandell and Lane (1989) made an attempt to evaluate empirically the nature of the contribution of architectural quality to the value of buildings. Their model postulated that equilibrium rent (the amount a tenant is willing to pay to rent a space, holding all other variables constant) and vacancy frequency and duration behaved as functions of both design and nondesign characteristics. They tested the model using disaggregate cross-sectional and longitudinal operating performance and amenity data from a set of 102 class A office buildings in Boston and Cambridge. Data on design quality for the set of buildings were provided by a detailed evaluation of each structure by a panel of architects. Their results confirmed a strong influence of design on rents; structures rated in the top $20 \%$ for design quality were predicted to extract almost $22 \%$ higher rents than those rated in the bottom $20 \%$. In contrast, the data showed a weak relationship between vacancy behavior and design quality. Finally, good design was shown to cost more to produce on average, but not necessarily in every case.

Glasock et al. (1990) analyzed office building rents using data for a 5-year period in a medium-sized city. Their results indicated that rent levels respond to various factors in the expected manner: Rents vary systematically across classes of buildings and locations, overall market conditions have a significant impact on rents, and contract variations are associated with rent differences. They also presented the first evidence at the building level on the rent-vacancy adjustment process and were able to show a significant relationship between rent changes and vacancies.

Mills (1992) analyzed 1990 office asking rents in the Chicago metropolitan area. Using a precise measure of the present value of the asking rent of a lease, he analyzed data from 543 offices that contained about $80 \%$ of the office space in the metropolitan area. The present value of asking rents was related to many building characteristics and to each building's location, demonstrating that asking rents depend on about 15 building characteristics and on a careful specification of its location.

Rosen (1974) provided the basic hedonic pricing framework that is most frequently used in property valuation literature. He generalized that the hedonic price function (HPF) covering any good or service consisted of a variety of utility-bearing characteristics. In office valuation literature, the use of hedonic modeling generally requires that structural characteristics be used as the independent variables determining value along with lease and location variables (Bollinger et al. 1998). In office valuation literature, the use of hedonic modeling generally requires that structural characteristics be used as the independent variables determining value along with lease and location variables (Bollinger et al. 1998). Examples of structural characteristics are total building square feet, number of floors, building age, and parking. Classification of space is also a structural characteristic, and it describes the quality of the amenities of the office space as follows:

- Class A: most technologically advanced, well-located, modern, commands premium rents.

- Class B: basic office space, value opportunity, some modern amenities.

- Class C: lowest grade, often old, few or no amenities.

Lease variables include information such as stop clauses, escalation rates, and gross or net lease. Location variables include distance from city center, distance from nearest highway interchange, and tax rates. With the exception of stop clause and escalation clause, which will be discussed later, this study includes all of the above variables. 


\section{HEDONIC MODEL Office Variables}

The structural and lease data for this study were provided by Grubb \& Ellis, a national commercial real estate brokerage firm. Because of the proprietary nature of the data, available office information tends to exhibit differences in the type of characteristics that are recorded from company to company. Each company's records reflect the data they think are most important and reflective of the local market. Therefore, this model contains some variables that are not prevalent in other literature but nonetheless present important and informative findings to those familiar with the local office market. The variables included in this study but not in other studies include the following: sublease, lease term, medical space, and regional classification (west, east, southwest, and south). Because the data were inconsistent, an additional variable, "unspecified," was added to denote the lack of regional information for a particular space.

The distance variables-distance from city center and nearest highway interchange-are measured along the street network. Public Square in downtown Cleveland was used as a proxy for city center. Another variable, denoted as multi-lease building, was added as a dummy indicator to account for the spatial relationship between different leases in the same building.

The dependent variable for this study is base (contract) rent. Some studies explored the use of effective rents as the dependent variable. Effective rents are estimated from the perspective of the property owners and are defined as the annual-equivalent cash flows of the present value of all cash flows that are explicitly identified in the lease contracts (Webb and Fisher 1996). These cash flows include contract rental rate, graduations in the contract rate, tenant improvements, moving allowances, buyout allowances, expense stops, broker commissions, and any other conditions that generate specific dollar receipts for the owner. As a result, effective rents have much more volatility and provide a more accurate and timely representation of trends in the price of space than either asking or contract rent. Because detailed lease-level data were not available and effective rent could not be calculated, base rent was used. Dummy variables serve as indicators for less detailed information such as sublease and net lease to account for variation in the data.

\section{Landscaping Variables}

The addition of landscaping variables added another potentially significant component to the make-up of rental rates for office space. Davey Resource Group personnel gathered detailed information for 85 office buildings in the greater Cleveland market. The landscaping at each of the 85 office buildings was evaluated for a variety of functions and graded using the classes Good, Moderate, Low, or None. The landscape variables were graded primarily on how well the landscape trees and plants provided a benefit at the current time. For example, mature trees typically are of greater value to noise attenuation than are small, immature trees. However, young trees planted in locations that gave them the potential to provide a function when they reached their expected size at maturity were given appropriate consideration for borderline judgments. For example, a row of young trees that provided low to moderate visual screening at the present time would be placed in the moderate class on the strength of the trees' potential to provide this function. The following functions provided by trees and landscape plants were reported on (the descriptions for each value were used as guidelines for qualitative grading more than as hard-and-fast quantitative measurements):

- Visual screening: Do landscape plants provide an effective visual barrier to adjacent properties and roads?

- Good-More than 50\% of objectionable views are screened from ground level.

- Moderate-25\% to 50\% of objectionable views are screened from ground level.

- Low-Less than 25\% of objectionable views are screened from ground level.

- None-No visual screening function of objectionable views.

- Noise attenuation: Are objectionable sounds such as noise from traffic noticeably less behind rows or groups of landscape plants?

- Good-Vegetation density and size is effective at significantly reducing noise.

- Moderate-Vegetation provides some reduction of noise at ground level.

- Low-Scattered woody vegetation probably offers limited noise reduction.

- None-Landscape is without woody vegetation.

- Shade to parking areas: What percentage of parking spaces are at least partially in shade during business hours during June, July, and August?

- Good-More than 10\%

- Moderate- $5 \%$ to $10 \%$

- Low-Less than 5\%

- None-0\%

- Shade to buildings: What percentage of building walls and windows are shaded during June, July, and August?

- Good-More than 25\%

- Moderate-10\% to 25\%

- Low-Less than $10 \%$

- None-0\%

- Recreational enhancement: Are landscape plants used to enhance outdoor picnic areas or gathering places?

- Good-Landscape plants are intentionally used to create gathering places for people or to create wildlife viewing areas.

- Moderate-Landscape plants may enhance but not necessarily define gathering places.

- Low-A few landscape plants are present but not designed with recreation or wildlife enhancement in mind.

- None-No landscape plants are used to attract people. 
- Space definition: Are landscape plants used to separate spaces such as vehicle and pedestrian areas?

- Good-Trees and other landscape plants clearly define areas of differing land use.

- Moderate-Landscape plants are used to separate vehicles from pedestrian areas.

- Low_Landscape plants are present, but not used effectively to define space.

- None-Landscape plants are not present.

- Aesthetics: Does the species selection and placement of landscape plants improve the appearance of the grounds throughout the year?

- Good-Trees and landscape plants offer color, texture, and variety throughout the seasons in interesting designs.

- Moderate-Trees and landscape plants considerably improve the appearance of the property.

- Low-Vegetation is present but is not particularly attractive or well maintained.

- None-Vegetation is not present or is in poor condition.

The questions presented with each of the function headings helped to guide field personnel on grading the landscaping functions as good, moderate, low, or none. Some of the functions such as visual screening, noise attenuation, and aesthetics were graded subjectively (no measuring instruments were used to gauge noise reduction or density of the vegetative screen). Other functions, including shade to buildings and parking lots, used ocularly estimated numeric ranges as previously indicated. Landscape plantings can be multifunctional (such as defining space and reducing noise) and in such a case would receive appropriate grades for each function. Similarly, a landscape planting may be effective at one function (such as visual screening) but poor at another (aesthetically poor). Examples of some of these landscaping functions are illustrated in Figures 1 through 6. Dummy variables were used to designate the rank of each observation. Operational definitions and sources for each of the variables that were used can be found in Table 1 .

At each of the properties, the type and amount of land cover was also evaluated. The following land cover classes were used:

- Building

- Pavement

- Turf

- Planting beds

- Tree canopy cover

- Water

- Other

Field personnel recorded the percentage of each land cover class at each property. Land cover percentage was determined by field personnel employing a random number table to select a compass bearing. This bearing was used to

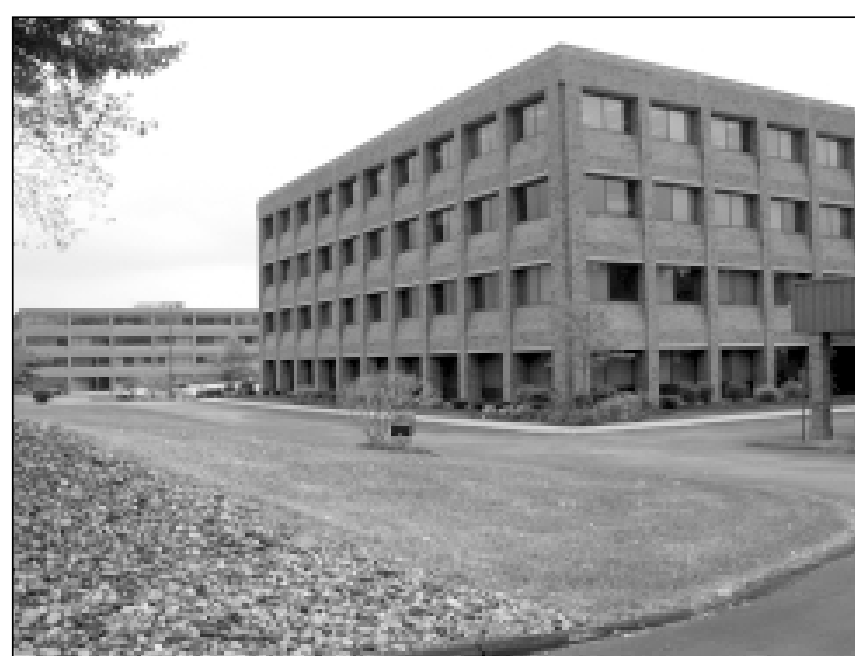

Figure 1. Landscaping with few functional benefits and low aesthetic value.

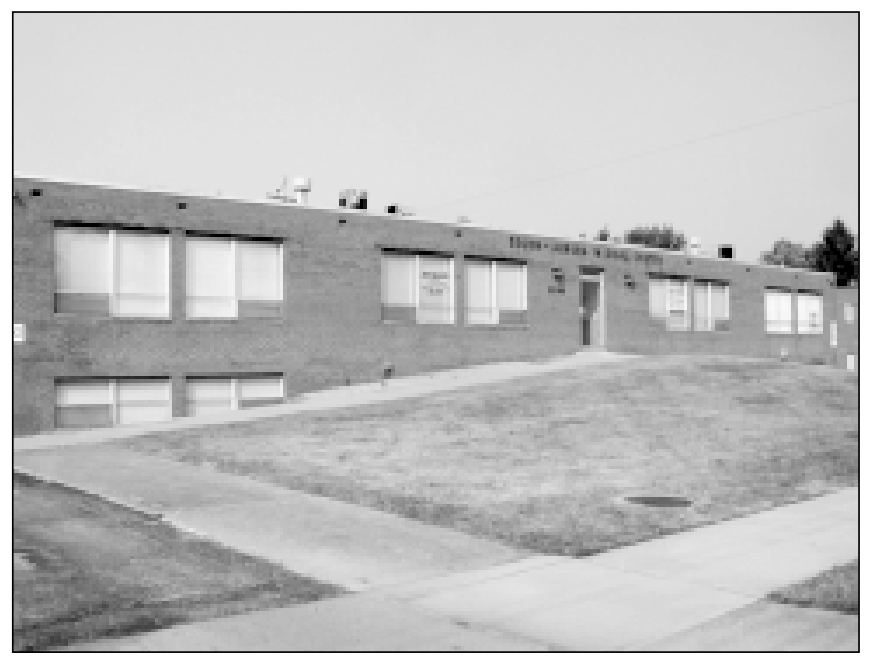

Figure 2. Landscaping with no functionality or aesthetic value.

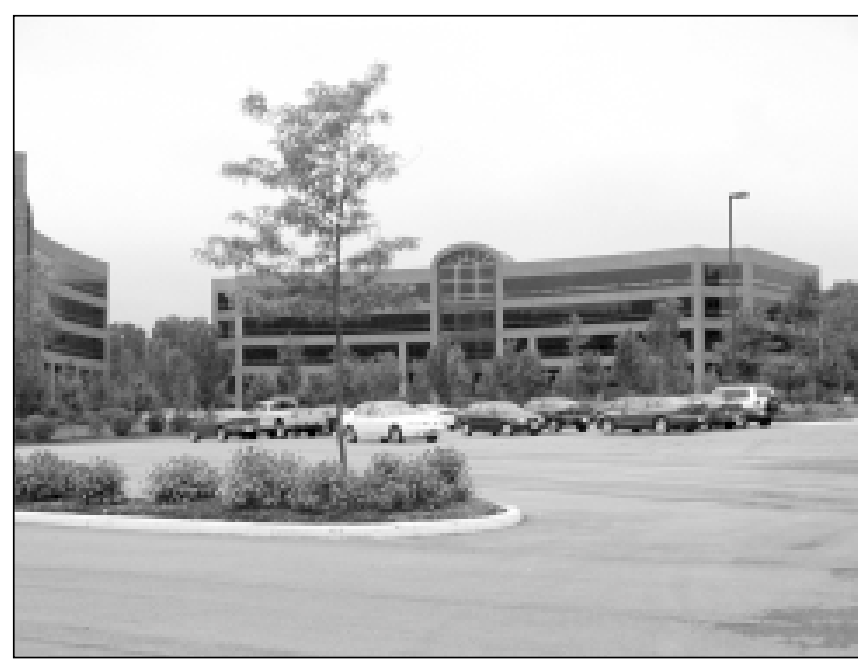

Figure 3. Very few office parking lots in the study area benefit from tree shade. 


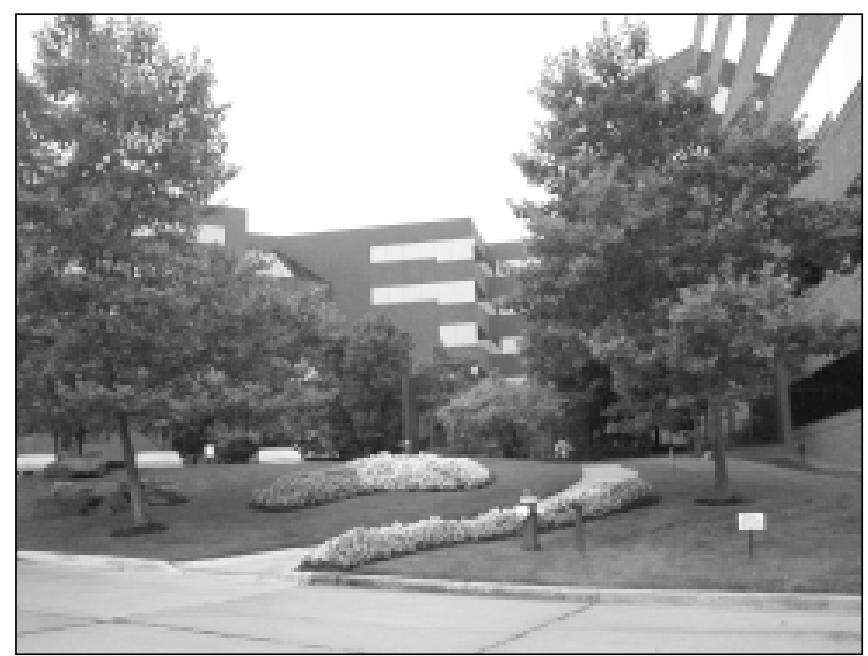

Figure 4. Trees providing good building shade and good visual screening.

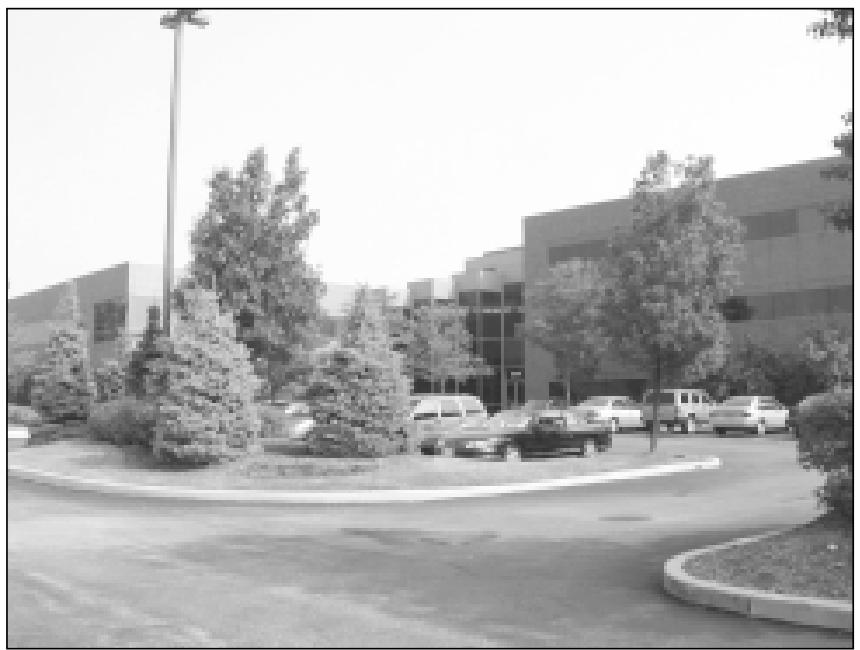

Figure 5. A landscape with moderate functionality and good aesthetics.

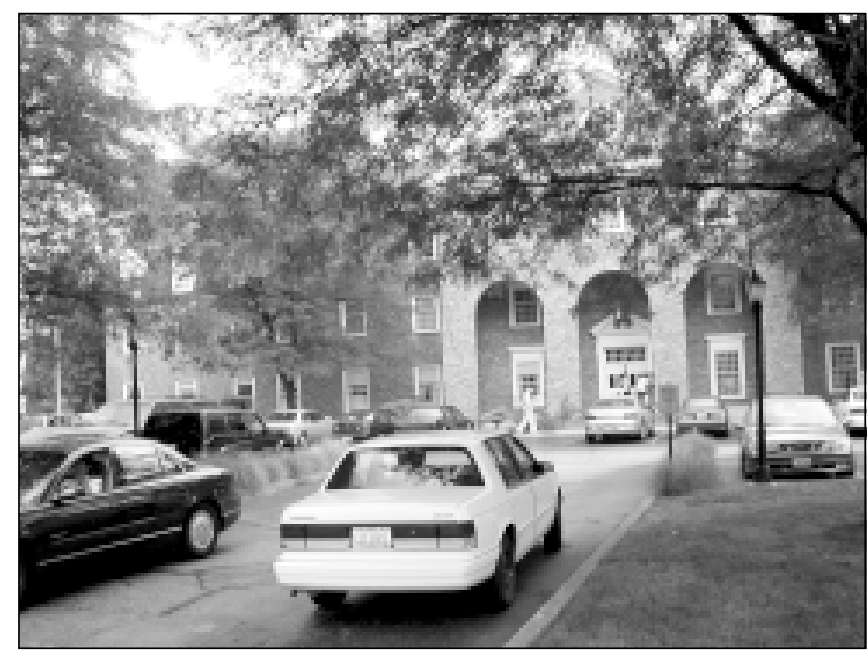

Figure 6. One of few examples of a mature landscape. pace a transect across the property while recording the cover type at regular intervals of six paces. In cases with overlapping land cover (such as the canopy of a tree overhanging pavement), the land cover visible from the sky was recorded (tree canopy is recorded instead of pavement). Three random transects were paced at each location, and the dot tallies used to calculate land cover percentages.

In addition to evaluating the functionality of the landscape and recording land cover, the overall landscaping was classified as mature, intermediate, or immature based on the size and age of the trees and other landscape plants. In general, mature landscapes will provide more functional benefits such as shading and noise attenuation than immature landscapes.

\section{Analytical Approach and Regression Procedure}

The determinants of office rents are investigated by regressing the annual contract rate per square foot of office space in an individual building on sets of explanatory variables that describe the location, typical leasing provisions and physical characteristics of the building. Our theoretical model suggests that landscaping characteristics should enter the model as structural determinants although for the purpose of this study they are listed separately.

Hence, the model that was employed in this research is as follows:

$$
R=\alpha+\beta_{1} S+\beta_{2} L+\beta_{3} L O C+\beta_{4} L A N D+\varepsilon
$$

where $R$ is a vector of contract rental rates, $\alpha$ is the regression constant, $\beta_{1}, \beta_{2}, \beta_{3}$, and $\beta_{4}$ are the estimated coefficient vectors of the structure, lease, location, and landscaping characteristics, respectively, and $\varepsilon$ is the error term that represents the primary source of error when trying to predict the value of rent in the model. The model shows the implicit value of an individual characteristic of the office space. For instance, it shows the value of the space classification (Class A, B, or C) as a portion of the total rent of the space.

The analysis for this study was performed in two steps. The first step involved creating a base model using the structural, lease, and location variables. Existing research on office space was used to determine which variables would be used and what their expected sign would be.

Once a satisfactory model was obtained, the landscaping variables were added. The initial addition of these variables was accomplished without any manipulation of the data. The results of this attempt provided little conclusive evidence of the effects of landscaping on rents, possibly due to collinearity, so a Principal Components Analysis (PCA) was conducted and the subsequent PCA-derived factors tested. This analysis was used to determine if any commonalities in the variables could be exploited. The first two 
Table 1. Operational definitions and data source.

\begin{tabular}{|c|c|c|}
\hline Variable & Definition & Source \\
\hline Effective tax rate & Effective tax rate of municipality & Cuyahoga Co. auditor \\
\hline East & ZIP codes available on request & Grubb \& Ellis \\
\hline South & ZIP codes available on request & Grubb \& Ellis \\
\hline Southwest & ZIP codes available on request & Grubb \& Ellis \\
\hline West & ZIP codes available on request & Grubb \& Ellis \\
\hline Class A & Class A office space (see literature review) & Grubb \& Ellis \\
\hline Class B & Class B office space (see literature review) & Grubb \& Ellis \\
\hline Class C & Class C office space (see literature review) & Grubb \& Ellis \\
\hline Class unspecified & No class specified & Grubb \& Ellis \\
\hline Medical & Classified as a medical office & Grubb \& Ellis \\
\hline Sublease & Space is sublet & Grubb \& Ellis \\
\hline Property size & Size of building in square feet & Grubb \& Ellis \\
\hline Transaction size & Size of transaction in square feet & Grubb \& Ellis \\
\hline Execution date 1995 & Lease executed in $1995^{\circ}$ & Grubb \& Ellis \\
\hline Execution date 1996 & Lease executed in 1996 & Grubb \& Ellis \\
\hline Execution date 1997 & Lease executed in 1997 & Grubb \& Ellis \\
\hline Execution date 1998 & Lease executed in 1998 & Grubb \& Ellis \\
\hline Execution date 1999 & Lease executed in 1999 & Grubb \& Ellis \\
\hline Execution date 2001 & Lease executed in 2001 & Grubb \& Ellis \\
\hline Lease term & Lease term in months & Grubb \& Ellis \\
\hline Multiple leases & More than one lease in building analyzed & Grubb \& Ellis \\
\hline Gross lease & Owner pays all expenses & Grubb \& Ellis \\
\hline Triple net lease & Tenant pays all expenses & Grubb \& Ellis \\
\hline Number of floors & Number of floors & Grubb \& Ellis \\
\hline Building age & 2001 less year built & Grubb \& Ellis \\
\hline Distance to public square & Straight line distance to public square & GIS \\
\hline Nearest highway interchange & Straight line distance to nearest interchange & GIS \\
\hline Good visual screen* & Trees block view of adjacent property & Davey \\
\hline Good noise barrier* & Trees block noise from adjacent road & Davey \\
\hline Good space definition* & Trees create spaces for human uses & Davey \\
\hline Good building shade ${ }^{*}$ & Trees shade walls and windows & Davey \\
\hline Good aesthetics* & Plantings well designed and maintained & Davey \\
\hline Percent canopy cover ${ }^{*}$ & Percentage of canopy cover & Davey \\
\hline Percent beds ${ }^{*}$ & Percentage of flower beds & Davey \\
\hline Percent turf* & Percentage of turf & Davey \\
\hline
\end{tabular}

${ }^{*}$ Denotes landscape vegetation variable evaluated in the field.

shade were temporarily combined into a single class and tested against the combined "moderate" and "good" values. The variables were subject to these various mathematical combinations so that the final analysis would reflect intuitive and theoretically satisfying results.

The final data set created two dummy variables for each of the functional landscaping attributes (visual screen, noise barrier, space definition, building shade, and aesthetics). These variables combined those sites with no or poor functional attributes to create the following variables: poor visual screen, poor noise barrier, poor space definition, poor building shade, and poor aesthetics. The other variables created for these functions combined moderate and good functional attributes into the following variables: good visual screen, good noise barrier, good space definition, good building

components of this analysis accounted for almost $90 \%$ of the variance in the model, although the loadings were such that their interpretation was not evident. While PCA typically allows for a more qualified interpretation of the dynamics underlying the price determination process, it did not in this case. The subsequent inclusion of these two components did not lead to better model performance. Therefore, individual landscape variables were analyzed rather than factors.

Using standard regression procedures, several combinations of landscaping arrangements were tested. For example, in the variable "Landscape Maturity," the sites graded "immature" and "intermediate" maturity were temporarily combined to form a single "immature/intermediate" class that was then tested against the single "mature" class. In another example, the "none" and "poor" values for building shade, and good aesthetics. Unlike the continuous landscaping variables, the dummy landscaping variables were assigned either a value of 1 (good) or 0 (poor); therefore, no standard deviation is reported in Table 2. A decision was made to exclude two of the original variables, which were recreational enhancement and vehicle shade. These factors were excluded because there was no theoretical basis to associate them with rental rates and because very few examples of trees or landscape plants that provided these functions were found. Also excluded was the maturity level of the landscaping because it did not offer any consistent explanatory power.

Finally, diagnostic procedures were conducted and were in very acceptable limits. The highest Variance Inflation Factor (VIF) was 6.69, indicating no serious multicollinearity issues. A VIF under 10 is the generally accepted standard. There were no extreme outliers removed from the data 
because there was no evidence they were not representative of the market. Scatter plots were examined for heteroscedasticity and no fanning was evident. The summary statistics for each of the variables is found in Table 2 .

\section{SUMMARY OF FINDINGS}

As can be seen from Table 3, the overall performance of the model is theoretically sound. With eight structural characteristics, eight lease variables, six location variables, and eight landscaping variables, the model has an $\mathrm{R}^{2}$ of .7311 . Most of the regression coefficients are consistent in sign and magnitude with theoretical expectations. A few notable exceptions include those leases executed between 1998 and 2001 , because the market shows some stagnation during those years. The distance to the city center is also insignifi- cant, as is building age. Log-linear forms of these variables were tested but failed to provide better overall performance. These variables remained in the equation because they are consistent with other literature, as did property size, transaction size, and number of floors. An attempt was made to include the effective age of the building (2001 less year of renovation) rather than the building's physical age, but inconsistency in the data excluded their use.

The inclusion of the landscaping variables provides interesting results. As would be expected, landscaping with a good aesthetic value added approximately $7 \%$ to the average rental rate of a building. Good building shade was also highly valued, positively impacting rental rates by about $7 \%$. Each of these variables is significant at the 95\% level, and the percentage increase is consistent with residential

Table 2. Descriptive statistics.

Continuous descriptors
Contract rate $\left(\$ / \mathrm{ft}^{2}\right)$
Contract rate $\left(\$ / \mathrm{m}^{2}\right)$
Effective tax rate $(\$ / \$ 1,000$ valuation)
Property (building) size $\left(\mathrm{ft}^{2}\right)$
Property (building) size $\left(\mathrm{m}^{2}\right)$
Transaction (office) size $\left(\mathrm{ft}^{2}\right)$
Transaction (office) size $\left(\mathrm{m}^{2}\right)$
Lease term (months)
Number of floors
Building age (years)
Distance/public square $(\mathrm{mi})$
Distance/public square $(\mathrm{km})$
Distance/highway interchange $(\mathrm{mi})$
Distance/highway interchange $(\mathrm{km})$

$\begin{array}{ll}\text { Dummy variables } & \text { Mean } \\ \text { South } & 0.2444 \\ \text { East } & 0.3481 \\ \text { Southwest } & 0.3407 \\ \text { West } & 0.0667 \\ \text { Class A } & 0.6259 \\ \text { Class B } & 0.3148 \\ \text { Class C } & 0.0296 \\ \text { Class unspecified } & 0.0259 \\ \text { Medical } & 0.0037 \\ \text { Sublease } & 0.0407\end{array}$

Continuous landscaping variables

Poor visual screen

Good visual screen

Poor noise barrier

Good noise barrier

Poor space definition

Good space definition

Poor aesthetics

Good aesthetics

Poor building shade

Good building shade

$\begin{array}{lllll}\text { Minimum } & \text { Maximum } & \text { Mean } & \text { Median } & \text { Std. dev. } \\ 5.25 & 25 & 16.42 & 16 & 3.39 \\ 56.51 & 269.1 & 176.73 & 172.22 & 36.49 \\ 40.37 & 89.8 & 53.95 & 54.55 & 11.08 \\ 10926 & 426960 & 79630.59 & 48631 & 56155.70 \\ 1015 & 39666 & 7398 & 4518 & 5217 \\ 240 & 134001 & 4860.62 & 2119 & 10594.22 \\ 22 & 12449 & 452 & 197 & 984 \\ 5 & 120 & 49.67 & 60 & 25.40 \\ 1 & 15 & 4.58 & 4 & 2.72 \\ 1 & 41 & 17.89 & 20 & 9.17 \\ 6.2745 & 20.4674 & 13.21 & 14.399 & 2.87 \\ 10.10 & 32.94 & 21.26 & 23.17 & 4.61 \\ 0.1924 & 3.6723 & 0.91 & 0.4877 & 0.75 \\ 0.31 & 5.91 & 1.47 & 0.78 & 1.21\end{array}$

Execution date 1995

Execution date 1996

Execution date 1997

Execution date 1998

Execution date 1999

Execution date 2000

Execution date 2001

Multiple leases

Gross lease

Triple net lease

$\begin{array}{ll}\text { Mean } & \text { Total N } \\ 0.1037 & 28 \\ 0.1556 & 42 \\ 0.1667 & 45 \\ 0.1222 & 33 \\ 0.1444 & 39 \\ 0.2037 & 55 \\ 0.1037 & 28 \\ 0.8148 & 220 \\ 0.9296 & 251 \\ 0.0704 & 19\end{array}$

\begin{tabular}{ll} 
\% of total \# of leases (270) & Total N \\
0.437 & 118 \\
0.563 & 152 \\
0.685 & 185 \\
0.311 & 84 \\
0.833 & 225 \\
0.167 & 45 \\
0.741 & 200 \\
0.259 & 70 \\
0.563 & 152 \\
0.437 & 118 \\
\hline
\end{tabular}

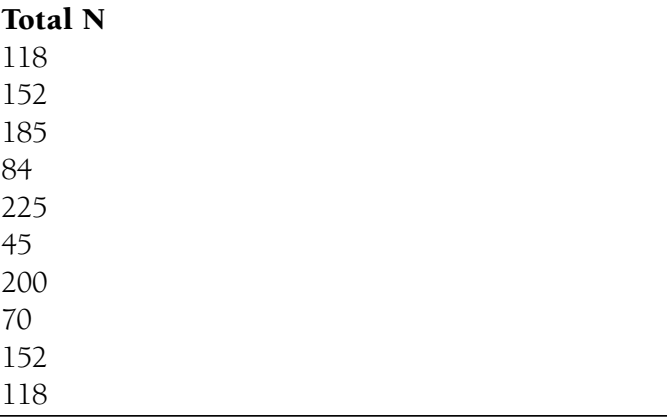


literature. Landscaping that functions as a noise barrier or that provides good space definition has no measurable impact, nor does incremental increases in the amount of canopy cover, turf, or flower beds. Somewhat surprising was the negative impact of landscaping that provided a good visual screen. Resulting in a loss in rent of approximately $7.5 \%$, this number is significant at the $95 \%$ level and has a t-value of -2.4080 .

\section{CONCLUSIONS}

This report investigates the effect of landscaping on the base rent of office buildings and is based on a detailed field survey of 85 buildings consisting of 270 individual and unique leases. All buildings are located within Cuyahoga County and are considered a part of the Cleveland, Ohio, metropolitan area. Conducted during the summer of 2001,

Table 3. Regression results.

\begin{tabular}{lllll}
\hline Variable & Value & Std. error & t value & $\operatorname{Pr}(>|\mathrm{t}|)$ \\
\hline Intercept & 228.1931 & 23.3508 & 9.7724 & 0.0000 \\
Effective tax rate & -1.0175 & 0.2017 & -5.0434 & 0.0000 \\
South & -3.9065 & 6.6429 & -0.5881 & 0.5570 \\
Southwest & -38.1453 & 6.1350 & -6.2176 & 0.0000 \\
West & -40.2846 & 7.2999 & -5.5185 & 0.0000 \\
Class B & -27.1664 & 4.8036 & -5.6554 & 0.0000 \\
Class C & -56.5621 & 9.2304 & -6.1278 & 0.0000 \\
Class unspecified & -80.5410 & 9.6517 & -8.3448 & 0.0000 \\
Medical & 11.0042 & 21.6879 & 0.5074 & 0.6124 \\
Sublease & -24.2143 & 6.6888 & -3.6201 & 0.0004 \\
Property size & 0.0001 & 0.0005 & 0.2231 & 0.8236 \\
Transaction size & -0.0029 & 0.0015 & -1.9624 & 0.0509 \\
Execution date 1995 & -19.4004 & 5.0509 & -3.841 & 0.0002 \\
Execution date 1996 & -17.7458 & 4.7636 & -3.7253 & 0.0002 \\
Execution date 1997 & -10.7633 & 4.3868 & -2.4536 & 0.0149 \\
Execution date 1998 & -0.6193 & 4.8579 & -0.1275 & 0.8987 \\
Execution date 1999 & 7.7225 & 4.6120 & 1.6744 & 0.0954 \\
Execution date 2001 & 5.9940 & 4.9111 & 1.2205 & 0.2235 \\
Lease term & 0.1427 & 0.0621 & 2.2963 & 0.0225 \\
Multiple leases & 3.6804 & 4.0746 & 0.9033 & 0.3673 \\
Triple net lease & -39.8277 & 6.1043 & -6.5246 & 0.0000 \\
Number of floors & 1.5374 & 1.1703 & 1.3137 & 0.1902 \\
Building age & -0.1662 & 0.2331 & -0.7132 & 0.4764 \\
Distance/public square & 0.8813 & 0.6671 & 1.321 & 0.1878 \\
Distance/highway interchange & 4.0891 & 1.8794 & 2.1757 & 0.0306 \\
Good visual screen & -14.0094 & 5.8179 & -2.408 & 0.0168 \\
Good noise barrier & 5.1835 & 3.5697 & 1.4521 & 0.1478 \\
Good space definition & 0.2194 & 5.6919 & 0.0386 & 0.9693 \\
Good building shade & 11.6008 & 5.3670 & 2.1615 & 0.0317 \\
Good aesthetics & 12.4585 & 6.1369 & 2.0301 & 0.0435 \\
Percent canopy cover & -0.3990 & 0.3503 & -1.1389 & 0.2559 \\
Percent beds & 0.5159 & 0.4283 & 1.2045 & 0.2296 \\
Percent turf & -0.0514 & 0.2058 & -0.2497 & 0.8030 \\
& & & &
\end{tabular}

Residual standard error: 20.16 on 237 d.f.

Multiple R2: 0.7311.

F-statistic: 20.13 on 32 and 237 d.f.; the p-value is 0 this survey focuses on the landscaping visible from all sides of a property and captures 11 different attributes dealing with ground and tree cover including functional aspects, maturity, and amount of landscaping. Some of the attributes were discarded due to the lack of theoretical justification or explanatory impact. The remaining landscaping features were then added to an array of structural, lease, and distance variables to determine the effects of landscaping and trees on office rental rates.

It appears that landscaping does have a positive impact on rental rates, although quality is essential. As would be expected, landscaping that is aesthetically pleasing provides an increase in office rental rates (Vandell and Lane 1989). This finding is consistent with residential literature that shows a positive impact of 3\% to 6\% (Henry 1994). The effect of good building shade is also consistent with literature that shows a $6 \%$ to $9 \%$ increase in residential property values (Morales et al. 1976). Finally, the effect of trees that provide a good visual screen negatively impacts rental rates. At first blush, it appears that this finding is contrary to intuitive judgment, but when compared to Payne's (1973) conclusions regarding excessive tree cover, it becomes much more palatable. This finding may indicate that office tenants value visibility over privacy.

In conclusion, our research findings are consistent with other literature on the subject. The model shows a clear relationship between quality landscaping and office rental rates.

\section{SUGGESTIONS FOR FURTHER RESEARCH}

The current study has some limitations, as conclusive as it might appear. First, the data set could be expanded to include office space represented by firms other than Grubb \& Ellis. The use of a single broker could produce potentially biased results, although the proprietary nature of the data effectively limits the ability to obtain information from a variety of sources. Second, a comparative study of the effects substantial, mature tree cover to sites with no tree cover should also be conducted, rather than attempting to draw conclusions from a percentage increase in the amount of landscaping. This study was unable to define "substan- 
tial" due to a lack of variation in the amount of canopy cover at the observed sites, although we were able to qualify the effectiveness of that cover. Third, a study of neighborhood characteristics may also provide insight into the importance of landscaping and tree cover. For instance, sites located in heavily wooded neighborhoods or near parks may charge higher rents than those that are not. Finally, a cost-benefit analysis should be conducted to determine the effect of planting and maintenance costs on the overall model.

\section{LITERATURE CITED}

Anderson, L.M., and H.K. Cordell. 1988. Influence of trees on residential property values in Athens, Georgia (USA): A survey based on actual sales prices. Landscape Urban Plann. 15:153-164.

Beckett, K.P., P. Freer-Smith, and G. Taylor. 2000. Effective tree species for local air-quality management. J. Arboric. 26:12-19.

Bollinger, C., K.R. Ihlanfeldt, and D.R. Bowes. 1998. Spatial variation in office rents within the Atlanta region. Urban Stud. 35(7):1097-1118.

Clapp, J.M. 1980. The intrametropolitan location of office activities. J. Region. Sci. 20:387-399.

Council of Tree and Landscape Appraisers. 2000. Guide for Plant Appraisal (9th ed.). International Society of Arboriculture. Champaign, IL. 143 pp.

Des Rosiers, F, M. Theriault, and P. Villeneuve. 2000. Sorting out access and neighbourhood factors in hedonic price modeling. J. Property. Invest. Fin. 18(3):291-315.

Dwyer, J.F., E.G. McPherson, H.W. Schroeder, and R.W. Rowntree. 1992. Assessing the benefits and costs of the urban forest. J. Arboric. 18:227-234.

Glasock, J.L., S. Jahanian, and C.F. Sirmans. 1990. An analysis of office market rents: Some empirical evidence. J. Am. Real Estate Urban Econ. Assoc. 105-119.

Henry, M.S. 1994. The contribution of landscaping to the price of single family houses: A study of home sales in Greenville, South Carolina. J. Environ. Hortic. 12(2):65-70.

Ip, D.W. 1996. Community tree planting: Early survival and carbon sequestering potential. J. Arboric. 22:222-228.

Laverne, R.J., and G.M. Lewis. 1996. The effect of vegetation on residential energy use in Ann Arbor, Michigan. J. Arboric. 22:234-243.

Martin, C.W., R.C. Maggio, and D.B. Appel. 1989. The contributory value of trees to residential property in the Austin, Texas, metropolitan area. J. Arboric. 15(3):72-75.

McPherson, E.G. 1998. Atmospheric carbon dioxide reduction by Sacramento's urban forest. J. Arboric. 24:215-223.

McPherson, E.G., and R.A. Rowntree. 1993. Energy conservation potential of urban tree planting. J. Arboric. 19:321-331.

McPherson, E.G., and J.R. Simpson. 1999. Carbon Dioxide Reduction Through Urban Forestry: Guidelines for Professional and Volunteer Tree Planters. USDA Forest Service General Technical Report PSW-GTR-171. 237 pp.
McPherson, E.G. J.R. Simpson, P.J. Peper, and Q. Xiao. 1999. Benefit-cost analysis of Modesto's urban forest. J. Arboric. 25:235-248.

Mills, Edwin S. 1992. Office rent determinants in the Chicago area. J. Am Real Estate Urban Econ. Assoc. 20(2).

Morales, D.J. 1980. The contribution of trees to residential property value. J. Arboric. 6(11)305-308.

Morales, D., B.N. Boyce, and R.J. Favretti. 1976. The contribution of trees to residential property value: Manchester, Connecticut. ASA Valuat. October-November.

Nowak, D.J. 1993. Compensatory value of an urban forest: An application of the tree-value formula. J. Arboric. 19:173-177.

Nowak, D.J., K.L. Civerolo, S.T. Rao, G. Sistla, C.J. Luley, and D.E. Crane. (In review). The impact of urban trees on ozone in the Northeastern United States. Atmos. Environ.

Payne, B.R. 1973. The twenty-nine tree home improvement plan. Nat. Hist. 82:74-75.

Peters, L. 1971. Shade and ornamental tree evaluation. J. For. 69:411-413.

Rosen, S. 1974. Hedonic prices and implicit markets: product differentiation in pure competition. J. Polit. Econ. 82(1):3455.

Schmitz, W.G. 1988. The name of the game in office space. Commerc. Invest. Real Estate J. May/June.

Scott, K.I., E.G. McPherson, and J.R. Simpson. 1998. Air pollution uptake by Sacramento's urban forest. J. Arboric. 24:224-234.

Simpson, J.R. 1998. Urban forest impacts on regional heating and cooling energy use: Sacramento County case study. J. Arboric. 24:201-214.

Simpson, J.R. and E.G. McPherson. 1996. Potential of tree shade for reducing residential energy use in California. J. Arboric. 22:10-18.

Sommer, R., F. Learey, J. Summit, and M. Tirrell. 1994. The social benefits of resident involvement in tree planting. J. Arboric. 20:170-175.

Sommer, R., J. Summit, F. Learey, and M. Tirrell. 1995. Social and educational benefits of a community shade tree program: A replication. J. Arboric. 21:260.

Sullivan, W.C. and F.E. Kuo. 1996. Do trees strengthen urban communities, reduce domestic violence? Arborist News 5(3):33-34.

Taylor, L., and V.K. Smith. 2000. Environmental amenities as a source of market power. Land Econ. 76(4):550-568.

Ulrich, R.S. 1986. Human responses to vegetation and landscapes. Landscape Urban Plann. 13:29-44.

Vandell, K.D., and J.S. Lane. 1989. The economics of architecture and urban design: Some preliminary findings. J. Am. Real Estate Urban Econ. Assoc. 17(2).

Webb, R., and J.D. Fisher. 1996. Development of an effective rent (lease) index for the Chicago CBD. J. Urban Econ. 39(1):1-19. 
Wheaton, W.C. 1984. The incidence of inter-jurisdictional differences in commercial property taxes. Natl. Tax J. 37:515-527.

Wolf, K.L. 1999. Grow for the gold: Trees in business districts. Tree Link bulletin of the Washington DNR Community Forestry Program Number 14. Washington State Department of Natural Resources. Olympia, WA. 4 pp.

Xiao, Q., E.G. McPherson, J.R. Simpson, and S.L. Ustin. 1998. Rainfall interception by Sacramento's urban forest. J. Arboric. 24:235-244.

Yee, J. 1989. Suburban Office Landscaping. J. Real Estate Devel. Winter.

Acknowledgments. Thanks to the National Urban and Community Forestry Advisory Council and the USDA Forest Service for providing partial funding for this research. Thanks also to Dierdre McGuane of Grubb \& Ellis, Inc., for providing data on commercial real estate properties.

\section{${ }^{1 *}$ Urban Forester/Ecologist \\ Davey Resource Group \\ 1500 North Mantua St. \\ Kent, $\mathrm{OH} 44240$, U.S.}

${ }^{2}$ Assistant Professor of Urban Studies

Savannah State University

Savannah, GA 31404, U.S.

*Corresponding author.

Résume. Cette étude a vérifié les effets des arbres et des aménagements paysagers sur le taux de location d'édifices à bureaux, et ce en se basant sur une comparaison entre 85 édifices à bureaux qui comprenaient 270 baux de location individuels et uniques dans le Cleveland métropolitain. Des données qui décrivent la quantité, la fonctionnalité et la qualité des aménagements ont été recueillies pour chacun des édifices, et ce incluant la maturité de l'aménagement, le pourcentage de couverture (arbre, gazon, pavage, etc.) et les attributs fonctionnels (ombrage de l'édifice, écran contre le bruit, définition de l'espace, récréation, écran visuel et esthétique). Une analyse de régression multiple, sous la forme d'une équation hédonique, a été faite afin d'isoler les effets économiques de ceux liés à l'aménagement paysager. Les données quant aux attributs des bureaux incluaient des variables sur les baux de location, les attributs physiques et les distances afin de calibrer le modèle de base; les données d'aménagement ont été incluses à l'équation hédonique afin de déterminer si des variables individuelles et/ou interactives avaient un effet quelconque sur les taux des contrats de location. L'analyse individuelle des variables a montré un effet positif très fort pour les édifices avec de bons aménagements paysagers esthétiques et avec des arbres qui ombrageaient bien la bâtisse. Inversement, un aménagement qui fournit un bon écran visuel produit des impacts négatifs sur les taux de location.

Zusammenfassung. Diese Studie untersuchte die Einflüsse von Bäumen und Landschaft auf die offiziellen Mietpreise und basiert auf einem Vergleich von 85 Bürogebäuden in der Geschäftsgegend von Cleveland, die 270 unabhängige Einheiten enthielten. Die Daten beschrieben die Quantität, Funktionalität du Qualität der Landschaft, wurden für jedes Gebäude erhoben und enthielten Angaben zum Entwicklungszustand der Landschaft, Prozentsatz der Bodenbedeckung (Bäume, Gras, Pflaster etc.) und funktioneller Angaben (Gebäudeschatten, Geräuschdämpfung, Raumdefinition, Erholung, Sichtschutz und Ästhetik) Multiple Regressionsanalysen in der Form einer hedonistischen Gleichung wurden durchgeführt, um die ökonomischen Effekte von Landschaftsbau zu isolieren. Dateninformationen über Pachtverträge, physikalische Attribute und Abstandsvariablen wurden verwendet, um das Basismodell zu kalibrieren und die Landschaftsbaudaten wurden der hedoistischen Gleichung hinzugefügt um zu bestimmen, ob individuelle und oder interaktive Variablen irgend einen Effekt auf den vertraglichen Mietzins hatten. Die individuelle Analyse der Variablen zeigte einen stark positiven Effekt für Gebäude mit ästhetischer Landschaftsgestaltung und für beschattete Gebäude. Auf der anderen Seite produzierte eine Landschaftsgestaltung mit guter Sichtschutzwirkung einen deutlich negativen Einfluss auf die Mietpreise.

Resumen. Este estudio investigó los efectos de los árboles en el paisaje sobre las tasas de renta de edificios de oficinas, con base en la comparación de 85 edificios de oficinas que comprenden 270 individuos en el área metropolitana de Cleveland. Los datos que describen la cantidad, funcionabilidad y calidad del paisaje fueron obtenidos de cada uno de los edificios, incluyendo la madurez del paisaje, el por ciento de cobertura (árboles, pasto, pavimentos, etc.) y los atributos funcionales (sombra a los edificios, amortiguación del ruido, definición del espacio, recreación, pantalla visual y valores estéticos). Un análisis de regresión múltiple en la forma de una ecuación fue conducido para aislar los efectos económicos del paisaje. Los datos de los atributos de las oficinas incluyendo menos información, atributos físicos y variables de distancia fueron usados para calibrar el modelo básico y los datos del paisaje fueron añadidos a la ecuación para determinar si las variables individuales y/o interacciones tenían algún efecto en las tasas de renta. El análisis individual de las variables mostró un fuerte efecto positivo para aquellos edificios con buena estética del paisaje y sombra provista por los árboles. Opuestamente, los paisajes que proporcionaron una pantalla visual produjeron impactos negativos significantes sobre las rentas. 